\title{
SYSTEMATIC REVIEW: PERSEPSI KONSUMEN TERHADAP LABEL TICK PADA PANGAN OLAHAN
}

\author{
Siti Maemunah ${ }^{*}$ \\ ${ }^{1}$ Fakultas Kesehatan Masyarakat, Universitas Indonesia, Indonesia \\ *Email: siti.mae1983@gmail.com
}

\begin{abstract}
ABSTRAK
Label FOP merupakan label yang dicantumkan pada bagian utama label. Label FOP bertujuan untuk memberikan informasi zat gizi kepada konsumen dalam format yang mudah dipahami. Salah satu label FOP yang dikembangkan yaitu label "green tick" atau dikenal juga dengan label "simple healthier choice tick (tick)", "healthier choice logo", "Choices logo", atau "pick the tick". Tujuan review artikel ini yaitu untuk mengidentifikasi persepsi label Tick pada label pangan berdasarkan pemahaman dan aspek penerimaan seperti kesukaan, sikap, daya tarik, dan persepsi beban kerja kognitif. Desain penelitian yang digunakan merupakan studi literatur menggunakan hasil penelitian yang dapat diakses melalui internet. Penelitian dilakukan pada bulan Maret hingga April 2020. Database yang digunakan yaitu PUBMED. Hasil penelitian menunjukkan label Tick lebih disukai oleh wanita dibandingkan laki-laki. Tingkat pendidikan menengah dan atas lebih menyukai label Tick. Responden dengan jenis pekerjaan sebagai karyawan lebih menyukai label Tick. Responden mendukung pencantuman label Tick pada produk pangan karena membantu konsumen untuk memilih produk pangan yang lebih sehat. Label Tick dapat diandalkan oleh konsumen dan mudah untuk diidentifikasi serta tidak membutuhkan waktu lama untuk memahami label Tick. Dari review literatur disimpulkan bahwa label Tick berperan membantu konsumen memilih produk pangan lebih sehat.
\end{abstract}

Kata kunci: label FOP, label tick, persepsi

\begin{abstract}
FOP label is a label that is listed on the main part of the label. The FOP label aims to provide nutritional information to consumers in an easily understood format. One of the developed FOP labels is the "green tick" label, also known as the "simple healthier choice tick (tick)" label, "healthier choice logo", "Choices logo", or "pick the tick". The aim of this article review is to identify Tick label perceptions on food labels based on understanding and acceptance aspects such as liking, attitudes, attractiveness, and perceptions of cognitive workload. The research design used is a literature study using research results that can be accessed via the internet. The study was conducted in March to April 2020. The database used is PUBMED. The results showed that the Tick label was preferred by women more than men overall. Secondary and high school education levels prefer the Tick label. Respondents with the type of job as employees prefer the Tick label. Respondents support the inclusion of the Tick label on food products because it helps consumers to choose healthier food products. Tick labels are reliable by consumers and are
\end{abstract}


IAKMI Jurnal Kesehatan Masyarakat Indonesia, Volume 1, No. 1, April 2020

Journal Homepage : http://jurnal.iakmi.id/index.php/IJKMI

ISSN 2721-9437 (Media Online)

easy to identify and don't require a long time to understand the Tick label. From a literature review it is concluded that the Tick label plays a role in helping consumers choose healthier food products.

Keywords: label FOP, label tick, perception

\section{PENDAHULUAN}

Label pangan merupakan sarana komunikasi antara produsen pangan dan konsumen serta menggambarkan faktor penting dalam keputusan pembelian produk oleh konsumen. Pelabelan pada pangan kemasan telah diterapkan secara sukarela oleh perusahaan pangan sejak awal abad ke-20. Pada akhir abad ke-20, pemerintah maupun organisasi non pemerintah mulai menerapkan sistem pelabelan zat gizi yang ditampilkan di bagian utama label (front-of-package (FOP)) dengan format yang sederhana, mudah dilihat dan dipahami konsumen. Informasi nilai gizi pada bagian utama label atau disebut juga dengan label FOP pertama kali diusulkan oleh WHO pada tahun 2004 dengan tujuan untuk meningkatkan kesehatan. Label front of pack (FOP) merupakan label ringkas yang terdapat di bagian depan produk pangan yang memuat informasi beberapa zat gizi (The Lancet Diabetes \& Endocrinology, 2018). Label zat gizi FOP bertujuan untuk memberikan informasi zat gizi kepada konsumen dalam format yang mudah dipahami. Label FOP diharapkan dapat meningkatkan perhatian konsumen terhadap informasi nilai gizi.

Berdasarkan penelitian meta analisis interdisipliner menunjukkan bahwa walaupun label FOP membantu konsumen mengidentifikasi produk yang lebih sehat, namun kemampuan untuk mendorong konsumen ke arah pilihan lebih sehat masih terbatas. Meskipun begitu, label FOP memberikan efek positif dalam meningkatkan persepsi dan perhatian konsumen terhadap kesehatan (Ikonen et al., 2019). Penelitian pengamatan mata (eye tracking) konsumen terhadap pangan yang diberi label FOP dan tidak diberi label FOP yang dilakukan (Bix et al., 2015) di Amerika Serikat menunjukkan label FOP meningkatkan perhatian konsumen untuk lebih lama melihat informasi zat gizi.

Banyak negara telah mengembangkan label FOP. Salah satu label FOP yang dikembangkan yaitu label "green tick" yang mirip juga dengan "simple healthier choice tick (tick)", "healthier choice logo", "healthy choices logo", "Choices logo", atau "pick the tick". "Green Tick" dikembangkan oleh Swedish Food Administration dan diperkenalkan oleh Heart Foundation Australia dan Selandia Baru pada tahun 1989 melalui program "Pick the Tick "(Liem et al., 2012; Méjean et al., 2014; Pauline et al., 2015). Setelah program "Pick the Tick" berjalan selama 10 tahun, sebanyak 89\% konsumen Australia mengenali label Tick dan mayoritas (59\%) konsumen membeli produk dengan label Tick (Liem et al., 2012). Label Tick mencerminkan kualitas gizi produk pangan dan hanya dicantumkan pada produk pangan yang lebih sehat (Pauline et al., 2015). Di Belanda dikenal dengan label "Choices" yang mencerminkan produk pangan mengandung kadar natrium, gula tambahan, lemak jenuh, lemak trans, dan energi dengan kadar lebih rendah dibandingkan dengan produk serupa dalam kategori produk yang sama (Vyth et al., 2010).

Tujuan review artikel ini yaitu untuk mengidentifikasi persepsi label Tick pada label pangan berdasarkan pemahaman dan aspek penerimaan seperti kesukaan, sikap, daya tarik, dan persepsi beban kerja kognitif.

\section{METODE PENELITIAN}

Desain penelitian merupakan studi literatur menggunakan hasil penelitian yang 
dapat diakses melalui internet. Penelitian ini dilakukan pada bulan Maret hingga April 2020. Peneliti menggunakan beberapa kata kunci dalam proses pencarian literatur. Database yang digunakan yaitu PUBMED. Kata kunci yang digunakan yaitu tick, tick logo, choices logo, dan perception.

Literatur yang digunakan dalam penelitian ini yaitu literatur yang dipublikasikan dari tahun 2010 sampai dengan tahun 2020. Berdasarkan hasil identifikasi studi literatur ditemukan 13 literatur. Peneliti kemudian melakukan screening literatur dengan menghilangkan duplikasi literatur. Kriteria inklusi yang digunakan yaitu persepsi konsumen terhadap label Tick pada pangan olahan. Kriteria ekslusi yang digunakan yaitu persepsi industri pangan terhadap kebijakan label Tick. Dari proses pencarian literatur menghasilkan 4 literatur yang memenuhi syarat kriteria inklusi dan ekslusi.

\section{HASIL DAN PEMBAHASAN}

\section{a. Data Demografi}

Hasil penelusuran literatur berdasarkan jenis kelamin menunjukkan bahwa wanita lebih menyukai label Tick dibandingkan lakilaki yaitu sebanyak 51,4\% (Méjean et al., 2013); 51,84\% (Méjean et al., 2014); dan 32,1\% (Pauline et al., 2015). Berdasarkan tingkat pendidikan, hasil penelusuran literatur menunjukkan sebanyak 50,3\% responden dengan tingkat pendidikan menengah dan atas menyukai label Tick (Méjean et al., 2013). Hal ini senada dengan penelitian Méjean et al., (2014) dimana sebanyak 49,51\% responden dengan tingkat pendidikan menengah dan atas menyukai label Tick. Sedangkan penelitian Pauline et al., (2015) memisahkan antara partispan dengan tingkat pendidikan hingga menengah dan responden dengan tingkat pendidikan hingga atas. Meskipun demikian, penelitian Pauline et al., (2015) menunjukkan hasil yang mirip dimana sebanyak 28,5\% responden dengan tingkat pendidikan menengah dan $34,2 \%$ responden dengan tingkat pendidikan atas yang menyukai label Tick.

Berdasarkan jenis pekerjaan, hasil penelusuran literatur menunjukkan bahwa responden dengan jenis pekerjaan sebagai karyawan lebih menyukai label Tick, yaitu sebanyak 42,4\% (Méjean et al., 2013), 40,52\% (Méjean et al., 2014), dan 32,3\% (Mejean et al., 2013).

\section{b. Data Persepsi terhadap label Tick Berdasarkan aspek kesukaan}

Penelitian Méjean et al., (2013) menunjukkan sebanyak $45,2 \%$ responden lebih suka produk pangan yang mencantumkan label Tick dan $40 \%$ responden menginginkan agar label Tick dapat dicantumkan pada bagian utama label, serta sebanyak 37\% responden menyatakan bahwa produk pangan dengan label Tick membantu konsumen untuk memilih produk pangan yang lebih sehat. Sedikit sekali responden yang tidak menyukai produk pangan dengan label Tick yaitu sebesar 2,9\%. Penelitian (Méjean et al., 2014) dan (Mejean et al., 2013) menunjukkan bahwa label Tick disukai oleh responden. Penelitian (Pauline et al., 2015) menunjukkan hal yang berbeda dimana 14,1\% responden menunjukkan bahwa label Tick membantu responden memilih produk pangan yang sehat. Sebanyak 9,5\% responden ingin label Tick dicantumkan pada bagian utama label, Sebanyak 34,7\% partispian mengapresiasi label Tick dan 10,7\% merasa label Tick merupakan pilihannya.

\section{Berdasarkan aspek sikap}

Penelitian (Mejean et al., 2013) menunjukkan sikap responden terhadap label Tick yaitu 7,8\% responden menolak, 2.3\% responden merasakan bingung, 33,6\% responden merasa kurang tertarik, 48,3\% responden menerima. Banyak konsumen yang mendukung penerapan label Tick. Hal 
ini sejalan dengan penelitian $S, S$ and MA, (2019) dimana mayoritas responden (80\%) mendukung penerapan label HCL.

\section{Berdasarkan aspek daya tarik}

Bagi konsumen label Tick dapat diandalkan untuk memberikan informasi zat gizi pada produk pangan. Penelitian (Méjean et al., 2013) menunjukkan sebanyak 39,9\% responden dapat mengandalkan label Tick, dan $28,0 \%$ responden merasakan bahwa label Tick memberikan semua informasi yang dibutuhkan. Penelitian (Mejean et al., 2013) menunjukkan sebanyak 53,5\% responden merasakan label Tick cukup berkontribusi memberikan informasi. Sebanyak 93,5\% responden merasakan Label Tick sangat mudah untuk diidentifikasi. Sebanyak 55,5\% responden merasakan label Tick sepenuhnya dapat diandalkan.

\section{Berdasarkan aspek persepsi beban kerja kognitif.}

Label Tick sangat mudah dipahami oleh konsumen. Penelitian Méjean et al., (2013) menunjukkan hanya $0,4 \%$ responden merasakan bahwa label Tick sulit untuk dipahami, sebanyak $1,2 \%$ responden membutuhkan waktu lama untuk memahami label Tick, dan 1,1\% responden merasakan label Tick membuat mereka tidak nyaman. Penelitian (Mejean et al., 2013) menunjukkan sebanyak $80,1 \%$ responden merasakan label Tick sangat mudah untuk dipahami. Hanya 1,7\% responden merasakan label Tick sangat komplek dan 18,2\% responden merasakan label Tick sedikit rumit. Penelitian (Pauline et al., 2015) menunjukkan sebanyak 20,3\% responden merasakan label Tick mudah dipahami, 17,9\% responden menyatakan label Tick cepat untuk dipahami, 12,3\% responden menyatakan label terlalu lengkap untuk dipahami, dan $4,6 \%$ responden menyatakan label Tick sangat lama untuk bisa dipahami.

Hal ini paralel dengan penelitian $S, S$ and MA, (2019) yang menunjukkan bahwa
$26 \%$ responden menyatakan kandungan zat gizi pada label HCL mudah untuk dipahami dan 51\% responden menyatakan label HCL dapat memberikan informasi zat gizi yang benar.

Sejalan dengan penelitian Vargas-Meza et al., (2019) dimana menunjukkan bahwa logo Healthy Choices memberikan pemahaman subyektif yang baik, dimana logo kesehatan merupakan logo yang mudah dipahami. Namun terdapat kelemahan dari logo ini dimana logo ini tidak memberikan informasi yang cukup kepada konsumen terkait jumlah kandungan zat gizi spesifik untuk konsumen dengan kondisi khusus seperti diabetes atau hipertensi.

Dalam artikel review yang dilakukan Hawley et al., (2013), melaporkan bahwa label FOP yang memuat informasi kalori, persen AKG, dan jumlah kalori harian menyajikan terlalu banyak informasi kepada konsumen. Konsumen menginginkan label FOP yang sederhana. Penelitian lain melaporkan konsumen mengalami kesulitan untuk memahami label FOP yang kompleks. Konsumen dapat memilih produk pangan yang lebih sehat dengan menggunakan format label FOP yang lebih sederhana seperti label Healthier Choice Tick (Feunekes et al., 2008).

Dalam hal rentang waktu yang dibutuhkan untuk menginterpretasikan label Tick, sebanyak 69,1\% responden membutuhkan rentang waktu yang cepat, $28,3 \%$ responden membutuhkan rentang waktu sedang, dan $2,6 \%$ responden membutuhkan rentang waktu lama untuk menginterpretasikan label Tick. Dalam hal ketidaknyamanan terhadap label Tick, sebanyak $72,9 \%$ responden tidak merasakan ketidaknyaman, 20,0\% responden merasakan sedikit tidak nyaman, dan 7,1\% responden merasakan tidak nyaman terhadap label Tick. 


\section{KESIMPULAN}

Dari data demografi terdapat beberapa variabel yang mempengaruhi respon konsumen terhadap label Tick. Dari variabel jenis kelamin terlihat bahwa wanita lebih dominan menyukai format label Tick dibandingkan laki-laki. Dari tingkat pendidikan, diketahui bahwa responden dengan tingkat pendidikan menengah dan atas lebih menyukai label Tick. Jenis pekerjaan responden turut berperan terhadap respon konsumen pada label Tick dimana dimana responden dengan jenis pekerjaan sebagai karyawan lebih menyukai label Tick. Label Tick membantu konsumen untuk memilih produk pangan yang lebih sehat. Hal ini paralel dengan hasil penelitian Feunekes et al., (2008) dimana menunjukkan bahwa label healthier choice Tick lebih efektif membantu konsumen memilih produk pangan yang lebih sehat. Label Tick cukup berkontribusi memberikan informasi produk pangan kepada konsumen. Konsumen pun merasakan label Tick mudah dipahami oleh konsumen. Mayoritas konsumen mendukung pencantuman label Tick pada produk pangan. Label Tick merupakan label dengan format yang sederhana. Konsumen tidak memerlukan waktu lama untuk menginterpretasikan label Tick. Namun, untuk konsumen dengan kondisi tertentu seperti konsumen dengan hipertensi ataupun diabetes, logo Tick tidak memberikan informasi yang cukup kepada konsumen terkait jumlah kandungan zat gizi spesifik pada produk pangan. Oleh karena itu, penting untuk menargetkan desain FOP terhadap populasi tertentu.

\section{DAFTAR PUSTAKA}

Bix, L. et al. (2015) 'To see or not to see: Do front of pack nutrition labels affect attention to overall nutrition information?', PLoS ONE, 10(10), pp. 1-
20. doi: 10.1371/journal.pone.0139732.

Feunekes, G. I. J. et al. (2008) 'Front-of-pack nutrition labelling: Testing effectiveness of different nutrition labelling formats front-of-pack in four European countries', Appetite, 50(1), pp. 57-70. doi: 10.1016/j.appet.2007.05.009.

Hawley, K. L. et al. (2013) 'The science on front-of-package food labels', Public Health Nutrition, 16(3), pp. 430-439. doi: $10.1017 /$ S1368980012000754.

Ikonen, I. et al. (2019) 'Consumer effects of front-of-package nutrition labeling: an interdisciplinary meta-analysis', Journal of the Academy of Marketing Science. Journal of the Academy of Marketing Science. doi: 10.1007/s11747-019-006639.

Liem, D. G. et al. (2012) 'Health labelling can influence taste perception and use of table salt for reduced-sodium products', Public Health Nutrition, 15(12), pp. 23402347. doi: $10.1017 / S 136898001200064 X$.

Mejean, C. et al. (2013) 'Consumer acceptability and understanding of front-of-pack nutrition labels', Journal of Human Nutrition and Dietetics, 26(5), pp. 494-503. doi: 10.1111/jhn.12039.

Méjean, C. et al. (2013) 'Perception of front-ofpack labels according to social characteristics, nutritional knowledge and food purchasing habits', Public Health Nutrition, 16(3), pp. 392-402. doi: 10.1017/S1368980012003515.

Méjean, C. et al. (2014) 'Association of perception of front-of-pack labels with dietary, lifestyle and health characteristics', PLoS ONE, 9(3). doi: 10.1371/journal.pone.0090971.

Pauline, D. et al. (2015) 'Effectiveness of frontof-pack nutrition labels in french adults: Results from the nutrinet-santé cohort study', PLoS ONE, 10(10), pp. 1-15. doi: 10.1371/journal.pone.0140898.

S, F., S, R. and MA, Z. (2019) 'Consumer Attitude Regarding Food Labelling and 
IAKMI Jurnal Kesehatan Masyarakat Indonesia, Volume 1, No. 1, April 2020

Journal Homepage : http://jurnal.iakmi.id/index.php/IJKMI

ISSN 2721-9437 (Media Online)

Perception of Healthier Choice Logo (HCL)', Biomedical Journal of Scientific $\mathcal{E}$ Technical Research, 17(1), pp. 1245912464.

doi: 10.26717/ bjstr.2019.17.002936.

The Lancet Diabetes \& Endocrinology (2018) 'Food nutritional information: transparency and public health', The Lancet Diabetes and Endocrinology. Elsevier Ltd, 6(7), p. 515 . doi: 10.1016/S2213-8587(18)30176-1.

Vargas-Meza, J. et al. (2019) 'Front-of-pack nutritional labels: Understanding by low- And middle-income Mexican consumers', PLoS ONE, 14(11), pp. 1-16. doi: 10.1371/journal.pone.0225268.

Vyth, E. L. et al. (2010) 'Actual use of a frontof-pack nutrition logo in the supermarket: Consumers motives in food choice', Public Health Nutrition, 13(11), pp. 1882-1889. doi: $10.1017 /$ S1368980010000637. 